\title{
NILAI BUDAYA DALAM MANTRA BERCOCOK TANAM PADI DI DESA RONGGO, KECAMATAN JAKEN, KABUPATEN PATI, JAWA TENGAH: KAJIAN FUNGSI SASTRA
}

\author{
Rukesi \\ E-mail: Rukesikesi@gmail.com \\ Sunoto \\ sunoto.fs@um.ac.id \\ Universitas Negeri Malang \\ Jalan Semarang 5, Malang 65145
}

\begin{abstract}
ABSTRAK: Fokus penelitin ini nilai budaya dalam mantra bercocok tanam padi. Penelitian ini menggunakan pendekatan kualitatif. Hasil penelitian menunjukkan bahwa mantra bercocok tanam padi mengandung nilai budaya dilihat dari pola hubungan manusia, yakni nilai budaya dalam hubungan manusia dengan diri sendiri memiliki enam wujud, nilai budaya dalam hubungan manusia dengan Tuhan memiliki enam wujud, nilai budaya dalam hubungan manusia dengan alam memiliki empat wujud, dan nilai budaya dalam hubungan manusia dengan manusia lain memiliki satu wujud.
\end{abstract}

Kata kunci : mantra, nilai budaya, sastra lisan

ABSTRACT: This research focus on cultural value in spells of rice plant planting. This research used a qualitative design. The results of this study shows that there is cultural value in spells of rice plant planting which is seen from the patterns of human relationships, that isi cultural values in the relationship between human and themselves have six form, cultural values in the relationship between human and God have six form, cultural values in relationship between human and nature have four form, and cultural values in relationship between human and other human have one form.

Keywords : spells, cultural values, oral literature

Mantra bercocok tanam padi di Desa Ronggo masih digunakan sampai saat ini. Mantra tersebut di-rapal ${ }^{1}$ pada tiga kegiatan selama proses bercocok tanam padi, meliputi membajak sawah, menamam padi, dan memanen padi. Sebelum merapalkan tiga mantra tersebut, perapal mantra terlebih dahulu merapalkan mantra pendayangan ${ }^{2}$ dengan tujuan untuk meminta izin kepada penguasa alam semesta. Mantra bercocok tanam padi di Desa Ronggo memiliki beberapa varian

\footnotetext{
${ }^{1}$ Dibaca.

${ }^{2}$ Mantra yang dirapal sebelum mantra membajak sawah, menanam padi, dan memanen padi.
} 
karena dituturkan secara lisan. Perbedaan pada varian tersebut ditemukan pada tataran bunyi, kata, dan kalimat, tidak pada maknanya.

Kalimat pada mantra bercocok tanam padi di Desa Ronggo mengandung sejumlah nilai. Nilai tersebut memuat pesan teladan yang tercermin melalui ucapan, tindakan, dan perilaku yang terlihat ketika masyarakat menjalankan proses pertanian padi dan pada kegiatan sehari-hari pada umumnya. Ucapan, tindakan, dan perilaku yang mencerminkan nilai tersebut membentuk suatu kebudayaan yang diwariskan secara turun-temurun oleh masyarakat pemiliknya. Maka dari itu, nilai yang dominan terkandung dalam mantra bercocok tanam padi adalah nilai budaya. Nilai budaya merupakan nilai yang mendarah daging dalam jiwa pemiliknya sehingga sulit digantikan dengan nilai dalam budaya lain dalam waktu singkat.

Penelitian terhadap nilai budaya dalam mantra bercocok tanam padi di Desa Ronggo perlu dilakukan berdasarkan beberapa alasan. Pertama, mantra bercocok tanam padi di Desa Ronggo masih digunakan sampai saat ini, akan tetapi regenerasi mantra tersebut kurang kuat di kalangan generasi muda. Kedua, mantra bercocok tanam padi di Desa Ronggo mengandung nilai budaya yang relevan dengan kehidupan modern. Berdasarkan alasan tersebut, perlu dilakukan penelitian terhadap mantra bercocok tanam padi di Desa Ronggo yang bertujuan memberikan pengetahuan kepada masyarakat untuk melestarikan mantra supaya tidak punah. Oleh karena itu, penelitian ini fokus pada nilai budaya dalam mantra bercocok tanam padi di Desa Ronggo berupa nilai budaya dalam hubungan manusia dengan diri sendiri, Tuhan, alam, dan manusia lain.

Bascom (dalam Sudikan, 2001: 109) menyatakan sastra lisan mempunyai empat fungsi, yaitu sebagai sebuah bentuk hiburan, sebagai alat pengesah pranata dan lembaga kebudayaan, sebagai alat pendidikan, dan sebagai alat pengesah serta pengawas agar norma masyarakat selalu dipatuhi oleh anggota kolektifnya. Fungsi tersebut tidak selalu hadir secara keseluruhan dalam suatu bentuk sastra lisan, khususnya mantra. Sorayah (2014) dalam penelitiannya terhadap mantra tandur di Desa Karangnunggal menemukan fungsi mantra tandur sebagai alat pendidikan, sistem proyeksi, dan sebagai pengesah kebudayaan. Pernyataan tersebut selaras dengan pernyataan Widodo (2012: 968-969) bahwa mantra bagi masyarakat 
Jawa berfungsi sebagai praktik mistisme yang di dalamnya terdapat kearifan lokal berbentuk nilai-nilai kultural.

Mantra merupakan salah satu bentuk sastra lisan. Mantra merupakan bagian dari kesusastraan lama karena mengandung unsur emosional, unsur keindahan berupa irama, dan unsur nilai moral karena mantra adalah asimilasi antara bahasa dan kepercayaan (Medan dalam Amir, 2013: 68-69). Sebagai bagian dari sastra lisan, mantra merupakan puisi rakyat atau sajak rakyat yang mempunyai ciri khusus berupa kalimatnya yang berbentuk terikat yang sudah ditentukan berdasarkan mantra, panjang pendek suku kata, lemah tekanan suara, atau berdasarkan irama (Danandjaja, 1994: 46). Selain itu, mantra juga merupakan fenomena budaya yang merepresentasikan nilai budaya yang mencerminkan kebudayaan yang dianggap ideal oleh kelompok masyarakat tempat mantra tersebut lahir dan berkembang.

Nilai budaya merupakan konsepsi-konsepsi yang hidup dalam pikiran sebagian besar warga masyarakat mengenai hal-hal yang dianggap bernilai dalam hidup (Koentjaraningrat, 2000: 25-26). Nilai budaya mempunyai bentuk yang didasarkan pada beberapa aspek. Djamaris, dkk (1996: 3) mengelompokkan nilai budaya berdasarkan pola hubungan manusia, yaitu hubungan antara manusia dengan Tuhan, alam, masyarakat, manusia lain, dan diri sendiri. Kelima pola hubungan manusia tersebut akan membentuk suatu kebudayaan tertentu dan melahirkan nilai-nilai tertentu dalam hubungannya. Nilai budaya mempunyai kedudukan dan fungsi yang strategis dan vital bagi kehidupan manusia. Saryono (2008: 16) memaparkan kedudukan dan fungsi nilai budaya menjadi lima jenis, yakni sebagai penggerak, pengendali, proyeksi dan utopia, tolok ukur, serta sebagai rujukan ucapan, tindakan, perbuatan, dan perilaku manusia.

\section{METODE}

Pendekatan yang digunakan dalam penelitian ini adalah kualitatif. Dalam penelitian ini, peneliti hadir sebagai instrumen utama yang bertugas mengumpulkan data di lokasi penelitian. Lokasi penelitian ini di Desa Ronggo, Kecamatan Jaken, Kabupaten Pati, Jawa Tengah. Data dalam penelitian ini berupa kata, frasa, atau kalimat dari transkripsi mantra bercocok tanam padi di Desa Ronggo yang mengandung nilai budaya. Sumber data dalam penelitian ini adalah 
mantra bercocok tanam padi di Desa Ronggo yang terdiri atas empat jenis, yakni mantra mantra pendanyangan berjumlah tiga varian, mantra membajak sawah berjumlah sembilan varian, mantra menanam benih padi berjumlah delapan varian, dan mantra memanen padi berjumlah sepuluh varian.

Teknik pengumpulan data dalam penelitian ini adalah wawancara, perekaman mantra dari informan, dan observasi. Analisis data dalam penelitian ini lebih dominan menggunakan sudut pandang etik karena informan penelitian belum dapat memberikan keterangan atau informasi yang mendalam terkait makna dan fungsi mantra. Proses analisis data dilakukan melalui tahap penelaahan data, reduksi data, penyajian data, dan penarikan kesimpulan. Pengecekan keabsahan data dilakukan dengan triangulasi sumber dan triangulasi metode.

\section{HASIL DAN PEMBAHASAN}

\section{Nilai Budaya dalam Hubungan Manusia dengan Diri Sendiri}

Nilai budaya dalam hubungan manusia dengan diri sendiri pada mantra bercocok tanam padi memiliki enam wujud sebagai berikut.

\section{Kerja Keras}

Kerja keras adalah suatu upaya yang terus dilakukan atau tidak pernah menyerah dalam menyelesaikan pekerjaan yang menjadi tugasnya sampai tuntas (Kesuma, dkk, 2012: 17-18). Nilai budaya kerja keras dalam mantra bercocok tanam padi ditemukan pada aspek mencari nafkah. Nilai budaya tersebut ditunjukkan melalui data Sanak sedulur goleko sandhang pangan dewe-dewe. Pada data tersebut, nilai budaya kerja keras diwujudkan melalui tindakan individu untuk memenuhi kebutuhan sandhang dan pangan. Nilai budaya kerja keras tersebut mengandung ajaran supaya manusia berusaha sungguh-sungguh untuk memperoleh apa yang dibutuhkan dan diinginkan. Hal tersebut sesuai dengan pernyataan Hasjim, dkk (1994: 21) bahwa kerja keras merupakan suatu tindakan tidak mudah putus asa yang dijadikan modal utama untuk mencapai kesuksesan sehingga apa yang dicita-citakan dapat tercapai. Kesuksesan yang tercermin dalam mantra bercocok tanam padi adalah terpenuhinya kebutuhan pribadi manusia, yaitu kebutuhan sandhang dan kebutuhan pangan.

Nilai budaya kerja keras dalam mantra bercocok tanam padi berisi gambaran mengenai harapan dan cita-cita masyarakat pemiliknya tentang 
kehidupan yang baik di masa mendatang. Pernyataan tersebut selaras dengan pernyataan Saryono (2008: 18) bahwa nilai budaya memiliki kedudukan sebagai proyeksi dan utopia hidup dan kehidupan yang berfungsi memandu dan menuntun ucapan, tindakan, perbuatan, dan perilaku manusia sesuai dengan harapan dan cita-cita yang tampak dalam nilai budaya yang dipeluknya. Nilai budaya kerja keras dalam mantra bercocok tanam padi berungsi sebagai pemandu dan penuntun manusia ketika berusaha mewujudkan harapan dan cita-cita untuk menjaga kelangsungan dan keselarasan hidup.

\section{Sabar}

Sabar merupakan sikap tahan dan tidak mudah emosi dalam melakukan sesuatu (Hasjim, dkk, 1994: 26). Nilai budaya sabar dalam mantra bercocok tanam padi ditemukan pada aspek pelaksanaan proses bercocok tanam padi. Nilai budaya tersebut ditunjukkan melalui data Tunggonono wite jari patang puluh papat dina empat papat. Pada data tersebut, nilai budaya sabar diwujudkan melalui sikap konsisten dalam melaksanakan proses pertanian dan dalam mengatasi masalah pertanian padi. Nilai budaya sabar tersebut mengandung ajaran bagi manusia untuk bersikap dan bertindak sesuai dengan komitmen supaya dapat mencapai suatu keberhasilan. Pernyataan tersebut sesuai dengan pernyataan Hasjim, dkk (1994: 26) bahwa segala sesuatu jika dihadapi dengan sabar akan memperoleh hasil yang baik. Hasil yang baik yang tercermin melalui nilai budaya sabar dalam mantra bercocok tanam padi adalah keberhasilan panen yang dapat digunakan sebagai cikal bakal untuk mencukupi kebutuhan pangan manusia.

Nilai budaya sabar dalam mantra bercocok tanam padi berisi gambaran mengenai harapan dan cita-cita masyarakat pemiliknya tentang kehidupan yang baik di masa mendatang. Pernyataan tersebut selaras dengan pernyataan Saryono (2008: 18) bahwa nilai budaya memiliki kedudukan sebagai proyeksi dan utopia hidup dan kehidupan manusia yang berfungsi memandu dan menuntun ucapan, tindakan, perbuatan, dan perilaku manusia sesuai dengan tujuan, harapan, dan cita-cita yang tampak dalam nilai budaya yang dipeluknya. Nilai budaya sabar dalam mantra bercocok tanam padi berfungsi memandu dan menuntun manusia dalam mewujudkan harapan dan cita-cita berupa keberhasilan panen. 


\section{Tanggung Jawab}

Tanggung jawab adalah sikap dan perilaku seseorang untuk melaksanakan tugas dan kewajiban sebagaimana seharusnya yang dilakukan terhadap diri sendiri, masyarakat, lingkungan, negara, serta Tuhan (Gunawan, 2012: 33). Nilai budaya tanggung jawab dalam mantra bercocok tanam padi ditemukan pada aspek pelaksaan proses bercocok tanam padi. Nilai budaya tersebut ditunjukkan melalui data yen kepacul paculku, yen keluku lukuku, yen keseblak pecutku, yen kidakan kebo sapiku. Berdasarkan data tersebut, nilai budaya tanggung jawab diwujudkan melalui sikap berhati-hati untuk mencegah adanya makhluk hidup yang tidak sengaja terkena alat pertanian ketika membajak sawah. Nilai budaya tanggung jawab mengandung ajaran supaya manusia bersikap hati-hati ketika menjalankan berbagai kewajiban saat melakukan pertanian supaya memperoleh keberhasilan panen. Pernyataan tersebut sesuai dengan pernyataan Sulaeman (1998: 79) bahwa orang yang bertanggung jawab dapat memperoleh kebahagiaan karena dapat menunaikan kewajiban. Kebahagiaan dalam mantra bercocok tanam padi berupa keberhasilan panen.

Nilai budaya tanggung jawab dalam mantra bercocok tanam padi menjadi pengendali yang berfungsi mengarahkan manusia untuk bersikap hati-hati ketika mengolah alam selama melaksanakan proses bercocok tanam padi. Kedudukan dan fungsi nilai budaya tersebut selaras dengan pernyataan Saryono (2008: 17) bahwa nilai budaya memiliki kedudukan sebagai pengendali yang berfungsi mengarahkan dan menjaga ucapan, tindakan, perbuatan, dan perilaku manusia. Nilai budaya tanggung jawab dalam mantra tersebut mengarahkan dan menjaga tindakan manusia supaya bersikap hati-hati ketika melaksanakan proses bercocok tanam padi sehingga tidak mengganggu atau menyakiti makhluk hidup di alam.

\section{Tidak Serakah}

Tidak serakah adalah sikap tidak ingin memiliki lebih dari yang dibutuhkan. Nilai budaya tidak serakah dalam mantra bercocok tanam padi ditemukan pada aspek pelaksaan proses bercocok tanam padi. Nilai budaya tersebut ditunjukkan melalui data Cukupno sak karepku tekakno sak semejaku iki. Berdasarkan data tersebut, nilai budaya tidak serakah diwujudkan melalui harapan dan tindakan manusia ketika mengolah tanah dan memanfaatkan tumbuhan padi. 
Nilai budaya tidak serakah dalam mantra tersebut mengandung ajaran supaya manusia tidak mengambil sesuatu dari alam melebihi apa yang dibutuhkan dan diusahakan. Ajaran tersebut selaras dengan pernyataan Roqib (2007: 65) bahwa masyarakat Jawa cenderung menganut falsafah dalam ungkapan nrima ing pandum yang berarti manusia hendaknya menerima apa yang sudah digariskan dan meminta sesuai dengan kebutuhan. Nilai budaya tidak serakah mengandung ajaran supaya manusia hendaknya tidak berharap dan tidak bertindak melebihi apa yang dibutuhkan supaya dapat merasa cukup dengan rezeki yang diperoleh.

Nilai budaya tidak serakah dalam mantra bercocok tanam padi menjadi rujukan yang berfungsi memberikan petunjuk kepada manusia supaya tidak mengeksploitasi sumber daya alam selama melaksanakan proses bercocok tanam padi. Kedudukan dan fungsi nilai budaya tersebut selaras dengan pernyataan Saryono (2008: 19) bahwa nilai budaya memiliki kedudukan sebagai sebagai rujukan yang berfungsi menunjukkan apa yang boleh dan baik serta apa yang tidak boleh dan tidak baik diikuti oleh ucapan, tindakan, perbuatan, dan perilaku manusia. Nilai budaya tidak serakah dalam mantra tersebut menjadi rujukan yang berfungsi menunjukkan apa yang boleh dan baik dilakukan manusia selama melaksanakan proses bercocok tanam padi, yaitu mengolah sumber daya alam sesuai kebutuhan pangan pribadi dan keluarga.

\section{Menjaga Kebaikan Diri}

Menjaga kebaikan diri merupakan sikap dan usaha manusia untuk menjaga kebaikan jasmani dan rohani. Nilai budaya menjaga kebaikan diri dalam mantra bercocok tanam padi ditemukan pada aspek pemanfaatan hasil panen. Nilai budaya tersebut ditunjukkan melalui data Bakal tak undhakake gedhong pengangen-angen. Berdasarkan data tersebut, nilai budaya menjaga kebaikan diri diwujudkan melalui harapan dan usaha manusia untuk menjaga kesehatan jasmani dan rohani dengan memanfaatkan hasil panen padi sebagai bahan untuk menghasilkan makanan. Nilai budaya menjaga kebaikan diri berhubungan dengan harapan manusia yang dijadikan panduan untuk bersikap dan bertindak supaya kelangsungan hidup terjaga dengan baik. Pernyataan tersebut selaras dengan pernyataan Sujarwa (2011: 168) bahwa manusia hendaknya memiliki harapan yang dapat mendorong manusia untuk memenuhi kebutuhan hidup berupa 
kebutuhan jasmani dan rohani. Nilai budaya menjaga kebaikan diri dalam mantra bercocok tanam padi yang berbentuk harapan dapat dijadikan sebagai pendorong bagi manusia untuk berusaha memanfaatkan hasil panen padi demi kebaikan, yakni untuk memenuhi kebutuhan jasmani dan rohani.

Nilai budaya menjaga kebaikan diri dalam mantra bercocok tanam padi berisi gambaran mengenai harapan dan cita-cita masyarakat pemiliknya tentang kehidupan yang baik di masa mendatang. Pernyataan tersebut selaras dengan pernyataan Saryono (2008: 17) bahwa nilai budaya memiliki kedudukan sebagai proyeksi dan utopia hidup dan kehidupan manusia yang berfungsi memandu dan menuntun ucapan, tindakan, perbuatan, dan perilaku manusia sesuai dengan harapan dan cita-cita yang tampak dalam nilai budaya yang dipeluknya. Nilai budaya menjaga kebaikan diri dalam mantra tersebut menjadi panduan untuk mewujudkan harapan berupa terjaganya kesehatan jasmani dan rohani supaya kelangsungan hidup terjaga dengan baik.

\section{Hemat}

Hemat merupakan sikap berhati-hati ketika membelanjakan harta. Nilai budaya hemat dalam mantra bercocok tanam padi ditemukan pada aspek pemanfaatan hasil panen. Nilai budaya hemat ditunjukkan melalui data Arep tak selehke ing nggone Mbok Sri gedhong pinumpuk. Berdasarkan data tersebut, nilai budaya hemat diwujudkan melalui tindakan manusia ketika memanfaatkan hasil bercocok tanam padi. Nilai budaya hemat mengandung ajaran supaya manusia tidak menghamburkan-hamburkan hasil panen mengingat bahwa hasil panen tersebut diperoleh melalui berbagai usaha. Nilai budaya hemat berhubungan dengan kebijaksanaan dalam memanfaatkan harta yang dimiliki yang diwujudkan melalui pengendalikan hawa nafsu dengan tidak menghambur-hamburkan harta yang dimiliki. Pernyataan tersebut selaras dengan pernyataan Saryono (2008: 10) bahwa kadar kebijaksanaan manusia bergantung pada kadar kedewasaan jiwa yang salah satunya diwujudkan dengan mengendalikan hawa nafsu. Pengendalian hawa nafsu tersebut akan melahirkan kebijaksanaan sebagai bentuk representasi nilai budaya hemat dalam memanfaatkan hasil bercocok tanam padi.

Nilai budaya hemat dalam mantra bercocok tanam padi menjadi pengendali yang berfungsi mengarahkan manusia ketika memanfaatkan hasil panen dengan 
hati-hati dan bijaksana. Kedudukan dan fungsi nilai budaya tersebut selaras dengan pernyataan Saryono (2008: 17) bahwa nilai budaya memiliki kedudukan sebagai pengendali yang berfungsi mengarahkan dan menjaga ucapan, tindakan, perbuatan, dan perilaku manusia. Nilai budaya hemat tersebut mengarahkan dan menjaga tindakan manusia supaya tidak menghamburkan-hamburkan harta berupa hasil panen padi.

\section{Nilai Budaya dalam Hubungan Manusia dengan Tuhan}

Nilai budaya dalam hubungan manusia dengan Tuhan pada mantra bercocok tanam padi memiliki enam wujud sebagai berikut.

\section{Berserah Diri Kepada Tuhan}

Berserah diri kepada Tuhan merupakan sikap manusia untuk menyerahkan diri secara total kepada Tuhan atau kekuatan tertinggi yang disembahnya (Sujarwa, 2011: 109). Nilai budaya berserah diri kepada Tuhan dalam mantra bercocok tanam padi ditemukan pada aspek keyakinan. Nilai budaya tersebut ditunjukkan melalui data wekase pendheto wali, gusti Allah kang ngideni. Berdasarkan data tersebut, nilai budaya berserah diri kepada Tuhan diwujudkan melalui kepercayaan dan tindakan manusia ketika menjalankan proses bercocok tanam padi. Nilai budaya berserah diri kepada Tuhan dalam mantra bercocok tanam padi merupakan bentuk penghayatan manusia tentang keberadaan Tuhan yang diwujudkan melalui kepercayaan terhadap kekuasaan dan kasih sayang Tuhan. Pernyataan tersebut selaras dengan pernyataan Djamaris, dkk (1994: 4) bahwa keberadaan manusia bergantung pada Tuhan karena Tuhan adalah penguasa mutlak atas diri manusia. Nilai budaya berserah diri kepada Tuhan dalam mantra bercocok tanam padi mengarahan manusia supaya menyerahkan hasil dari segala usaha kepada Tuhan karena sejatinya manusia bergantung kepada kekuasaan Tuhan.

Nilai budaya berserah diri kepada Tuhan dalam mantra bercocok tanam padi menjadi pengendali yang berfungsi mengarahkan manusia supaya berserah diri kepada Tuhan atas segala usaha yang telah dilakukan untuk memenuhi kebutuhan hidup melalui bercocok tanam padi. Kedudukan dan fungsi nilai budaya tersebut selaras dengan pernyataan Saryono (2008: 17) yang menyatakan bahwa nilai budaya memiliki kedudukan sebagai pengendali yang berfungsi 
mengarahkan dan menjaga ucapan, tindakan, perbuatan, dan perilaku manusia. Nilai budaya berserah diri kepada Tuhan dalam mantra tersebut mengarahkan manusia supaya menyerahkan hasil dari segala usaha selama melaksanakan proses bercocok tanam padi.

\section{Meminta Perlindungan dan Pertolongan kepada Tuhan}

Meminta perlindungan dan pertolongan kepada Tuhan berhubungan dengan sikap religius manusia yang memercayai bahwa Tuhan adalah penguasa alam semesta. Nilai budaya meminta perlindungan dan pertolongan kepada Tuhan dalam mantra bercocok tanam padi ditemukan pada aspek pelaksanaan proses bercocok tanam padi. Nilai budaya tersebut ditunjukkan melalui data Sak rina sak wengine aja ana alangan apa-apa dan Muga selamet sing ngawiti, sing dikawiti selamet. Berdasarkan data tersebut, nilai budaya meminta perlindungan dan pertolongan kepada Tuhan diwujudkan melalui permohonan supaya segala rintangan dapat diselesaikan serta permohonan keselamatan dan kesehatan selama menjalankan proses bercocok tanam padi. Permohonan tersebut sebagai bentuk pengakuan manusia bahwa Tuhan adalah pemilik kekuasan dan kekuatan tertinggi. Pernyataan tersebut selaras dengan pernyataan Saryono (2009: 13) bahwa dalam sastra terkandung ajaran sufisme yang berisi kepercayaan bahwa keadaan atau kondisi manusia merupakan rahmat atau anugerah dari Tuhan. Nilai budaya dalam mantra tersebut mengandung kepercayaan bahwa keadaan atau kondisi manusia yang dapat menyelesaikan rintangan, kesehatan, serta keselamatan selama melaksanakan pertanian padi terjadi atas kehendak Tuhan.

Nilai budaya meminta perlindungan dan pertolongan kepada Tuhan dalam mantra bercocok tanam padi menjadi pengendali yang berfungsi mengarahkan dan menjaga tindakan manusia untuk meminta perlindungan dan pertolongan kepada Tuhan selama melaksanakan proses bercocok tanam padi. Kedudukan dan fungsi nilai budaya tersebut selaras dengan pernyataan Saryono (2008: 17) bahwa nilai budaya memiliki kedudukan sebagai pengendali yang berfungsi mengarahkan dan menjaga ucapan, tindakan, perbuatan, dan perilaku manusia. Nilai budaya tersebut mengarahkan manusia untuk memohon perlindungan dan pertolongan kepada Tuhan supaya segala rintangan selama proses bercocok tanam padi dapat teratasi 
dan supaya mendapatkan kesehatan dan keselamatan sehingga proses bercocok tanam padi dapat berjalan baik.

\section{Memercayai Kebaikan dan Keburukan Berasal dari Tuhan}

Nilai budaya memercayai kebaikan dan keburukan berasal dari Tuhan berhubungan dengan kepercayaan manusia terhadap Takdir. Kepercayaan terhadap takdir berisi keyakinan bahwa manusia tidak dapat menolak kehendak Tuhan (Djamaris, 1996: 31). Nilai budaya memercayai kebaikan dan keburukan berasal dari Tuhan dalam mantra bercocok tanam padi ditemukan pada aspek keyakinan. Nilai budaya tersebut ditunjukkan melalui data Minalallahi ala untung saking pengeran. Berdasarkan data tersebut, nilai budaya memercayai kebaikan dan keburukan berasal dari Tuhan diwujudkan melalui kepercayaan bahwa keberuntungan yang berisi kebaikan dan keburukan yang diterima manusia merupakan kehendak Tuhan. Nilai budaya tersebut mengandung kepercayaan mengenai takdir Tuhan yang berhubungan dengan keberhasilan dan kegagalan panen yang menuntun manusia supaya lapang dada menerima hasil panen kelak. Pernyataan tersebut selaras dengan pernyataan Saryono (2008: 84-85) bahwa kelapangdadaan manusia Jawa berkenaan dengan kerelaan dan kesediaan dalam hati, pikiran, dan perasaan ketika menghadapi dan menerima segala peristiwa dan kenyataan. Nilai budaya memercayai kebaikan dan keburukan berasal dari Tuhan mengajarkan manusia supaya menerima dengan lapang dada kebaikan atau kegagalan yang dikehendaki Tuhan.

Nilai budaya memercayai kebaikan dan keburukan berasal dari Tuhan dalam mantra bercocok tanam padi menjadi pengendali yang berfungsi mengarahkan manusia untuk memercayai bahwa keberhasilan atau kegagalan panen terjadi atas kehendak Tuhan. Kedudukan dan fungsi nilai budaya tersebut selaras dengan pernyataan Saryono (2008: 17) bahwa nilai budaya memiliki kedudukan sebagai pengendali yang berfungsi mengarahkan dan menjaga ucapan, tindakan, perbuatan, dan perilaku manusia. Nilai budaya tersebut mengarahkan manusia untuk memercayai bahwa keberuntungan, kebaikan, dan keburukan yang diterima dalam bercocok tanam padi berasal dari Tuhan. 


\section{Meminta Restu kepada Tuhan}

Meminta restu kepada Tuhan merupakan keyakinan dan sikap manusia untuk meminta izin terlebih dahulu kepada Tuhan sebelum bertindak melakukan sesuatu. Nilai budaya meminta restu kepada Tuhan dalam mantra bercocok tanam padi ditemukan pada aspek pelaksanaan proses bercocok tanam padi. Nilai budaya tersebut ditunjukkan melalui data Ibu bumi bapa biang, aku njaluk sandhang karo pangan. Berdasarkan data tersebut, nilai budaya meminta restu kepada Tuhan diwujudkan melalui permintaan izin sebelum melaksanakan proses bercocok tanam padi sebagai bentuk doa kepada Tuhan yang diyakini mempunyai kekuatan yang lebih besar daripada manusia. Pernyataan tersebut selaras dengan pernyataan Sulaeman (1998: 83) bahwa doa merupakan proses hubungan antara manusia dengan Tuhan yang berisi harapan. Nilai budaya meminta restu kepada Tuhan berisi doa supaya harapan untuk memperoleh keberhasilan panen dapat tercapai. Selain itu, nilai budaya meminta restu kepada Tuhan juga mengajarkan manusia untuk menunjukkan rasa cinta kepada Tuhan dengan memberikan persembahan sebagai bentuk pemujaan. Pernyataan tersebut selaras dengan pernyataan Sujarwa (2011: 101) bahwa pemujaan merupakan perwujudan cinta manusia kepada Tuhan sekaligus sebagai pengakuan manusia atas kebesaran Tuhan. Berdasarkan pernyataan tersebut, nilai budaya meminta restu kepada Tuhan diwujudkan melalui permintaan izin, doa, dan pemujaan.

Nilai budaya meminta restu kepada Tuhan dalam mantra bercocok tanam padi menjadi pengendali yang berfungsi mengarahkan ucapan dan tindakan manusia untuk meminta izin kepada Tuhan terlebih dahulu sebelum mulai melaksanakan proses bercocok tanam padi dan untuk menunjukkan rasa cinta kepada Tuhan. Kedudukan dan Fungsi nilai budaya tersebut selaras dengan pernyataan Saryono (2008: 17) bahwa nilai budaya memiliki kedudukan sebagai pengendali yang berfungsi mengarahkan dan menjaga ucapan, tindakan, perbuatan, dan perilaku manusia. Nilai budaya tersebut mengarahkan manusia untuk meminta restu kepada Tuhan ketika melaksanakan proses bercocok tanam padi supaya padi dapat tumbuh dengan baik. 


\section{Memercayai Hidup dan Mati Ada pada Kuasa Tuhan}

Memercayai hidup dan mati ada pada kuasa Tuhan berisi kepercayaan bahwa hidup dan mati adalah milik Tuhan (Sulaeman, 1998: 90). Nilai budaya memercayai hidup dan mati ada pada kuasa Tuhan dalam mantra bercocok tanam padi ditemukan pada aspek keyakinan. Nilai budaya tersebut ditunjukkan melalui data Moyog-moyog kersanae Allah suket mati wijine pari dadi. Berdasarkan data tersebut, nilai budaya memercayai hidup dan mati ada pada kuasa Tuhan diwujudkan melalui kepercayaan bahwa hidup dan matinya tanaman padi atau gulma ada pada kuasa Tuhan. Nilai budaya tersebut dijadikan panduan untuk memohon dan berharap kepada Tuhan supaya padi tumbuh dengan baik dan gulma mati. Pernyataan tersebut selaras dengan pernyataan Sulaeman (1998: 91) bahwa keyakinan yang ada dalam hidup manusia dijadikan sebagai pacuan untuk berusaha supaya cita-cita dan harapan dapat terwujud. Keyakinan dalam nilai budaya tersebut mengajarkan manusia untuk senantiasa berusaha keras dalam melaksanakan proses bercocok tanam padi dan senantiasa memohon kepada Tuhan supaya kehidupan dan pertumbuhan tanaman padi terjaga dengan baik dan gulma tanaman dapat musnah.

Nilai budaya memercayai hidup dan mati ada pada kuasa Tuhan dalam mantra bercocok tanam padi menjadi pengendali yang berfungsi mengarahkan manusia untuk memohon kepada Tuhan supaya kehidupan dan pertumbuhan tanaman padi terjaga dengan baik dan gulma tanaman dapat musnah sehingga dapat diperoleh keberhasilan panen. Kedudukan dan fungsi nilai budaya tersebut selaras dengan pernyataan Saryono (2008: 17) bahwa nilai budaya memiliki kedudukan sebagai pengendali yang berfungsi mengarahkan dan menjaga ucapan, tindakan, perbuatan, dan perilaku manusia. Nilai budaya tersebut mengarahkan manusia untuk memercayai bahwa kehidupan dan kematian makhluk hidup terjadi atas kehendak Tuhan.

\section{Memercayai Adanya Hukuman dari Tuhan}

Hukuman dari Tuhan merupakan siksaan yang diperoleh manusia atau makhluk hidup lain jika melanggar perintah dan larangan Tuhan (Sujarwa, 2011: 82). Nilai budaya memercayai adanya hukuman dari Tuhan dalam mantra bercocok tanam padi ditemukan pada aspek keyakinan. Nilai budaya tersebut 
ditunjukkan melalui Nyewak wereng walang angin walang sangit suntep sak liyaliyane, aja ganggu-ganggu Mbok Sriku. Nek ganggu Mbok Sriku bakale dendaning Allah. Berdasarkan data tersebut, nilai budaya memercayai adanya hukuman dari Tuhan diwujudkan melalui kepercayaan bahwa hama dan gulma yang mengganggu proses bercocok tanam padi akan mendapat hukuman dari Tuhan. Nilai budaya tersebut mengandung ajaran kepada manusia dan makhluk hidup lain supaya bersikap baik ketika bertindak untuk memenuhi kebutuhan hidup dengan tidak saling menganggu dan tidak saling menyakiti. Pernyataan tersebut selaras dengan pernyataan Sulaeman (2011: 83) bahwa karya seni yang mengajarkan adanya siksaan dari Tuhan dapat memberikan teladan bagi manusia untuk berperilaku baik dengan tidak berperilaku sadis yang tidak mengenal perikemanusiaan. Berdasarkan pernyataan tersebut, mantra, sebagai bentuk dari karya seni masyarakat, mengandung nilai budaya yang dapat dijadikan teladan ketika manusia bertindak untuk memenuhi kebutuhan hidup sehingga dapat terhindar dari hukuman atau siksaan Tuhan.

Nilai budaya memercayai adanya hukuman dari Tuhan dalam mantra bercocok tanam padi menjadi pengendali yang berfungsi mengarahkan manusia untuk memercayai bahwa barang siapa yang mengganggu atau menyakiti makhluk hidup lain akan mendapatkan hukuman dari Tuhan. Kedudukan dan fungsi nilai budaya tersebut selaras dengan pernyataan Saryono (2008: 17) bahwa nilai budaya memiliki kedudukan sebagai pengendali yang berfungsi mengarahkan dan menjaga ucapan, tindakan, perbuatan, dan perilaku manusia. Nilai budaya tersebut mengarahkan manusia untuk memercayai bahwa Tuhan akan memberikan hukuman kepada makhluk-Nya jika mengganggu atau menyakiti kehidupan makhluk hidup lain.

\section{Nilai Budaya dalam Hubungan Manusia dengan Alam}

Nilai budaya dalam hubungan antara manusia dengan alam dalam mantra bercocok tanam memiliki empat wujud sebagai berikut.

\section{Percaya Adanya Makhluk Gaib di Alam Semesta}

Percaya adanya makhluk gaib di alam semesta merupakan keyakinan yang mengandung konsepsi tentang adanya dewa, makhluk-makhluk halus, seperti roh leluhur, dan konsepsi tentang yang tinggi dan pencipta alam (Sujarwa, 2011: 107). 
Nilai budaya percaya adanya makhluk gaib dalam mantra bercocok tanam padi ditemukan pada aspek keyakinan mengenai adanya makhluk gaib ciptaan Tuhan. Nilai budaya tersebut ditunjukkan melalui beberapa data yang di dalamnya menyebut makhluk gaib dengan sirenggana sirenggani, kumbayana kumbayani, siduryana siduryani, seluman, tirta kencana, kaki anta buga, nini anta buga, kaki wiredi, nini wiredi, kaki murti, nini murti, buyutan, kaki dengeng, nini dengeng, kaki demit, nini demit, danyang, dan sing ning tengah sing ning pinggir. Berdasarkan data tersebut, nilai budaya percaya adanya makhluk gaib diwujudkan melalui kepercayaan untuk menjaga perilaku ketika melaksanakan proses bercocok tanam padi karena di alam juga hidup makhluk gaib. Nilai budaya tersebut mengarahkan manusia untuk menjaga keharmonisan antarsesama makhluk ciptaan Tuhan dengan sikap sopan santun dan penyediaan sesaji supaya makhluk gaib tersebut tidak mengganggu proses bercocok tanam padi. Pernyataan tersebut selaras dengan pernyataan Kodiran (2002: 347) bahwa orang Jawa memiliki kepercayaan kepada arwah atau roh leluhur dan makhluk halus yang menempati alam sekitar. Masyarakat Jawa juga memercayai jika ingin hidup tanpa gangguan makhluk gaib perlu melakukan sesuatu untuk mempengaruhi alam semesta, misalnya menjaga perilaku dan menyediakan sesaji. Nilai budaya percaya adanya makhluk gaib dalam mantra bercocok tanam padi mengarahkan perilaku manusia untuk menjaga keharmonisan dengan makhluk gaib yang hidup di alam.

Nilai budaya percaya adanya makhluk gaib di alam dalam mantra bercocok tanam padi merupakan perwujudan dari usaha manusia untuk mencari keselarasan dengan alam. Pernyataan tersebut selaras dengan pernyataan Koentjaraningrat (2000: 29) bahwa nilai budaya menjadi dasar untuk membentuk ide, pola pikir, dan perilaku mansia untuk mencari keselarasan dengan alam. Dengan demikian, nilai budaya percaya adanya makhluk gaib dalam mantra bercocok tanam padi berkedudukan menjadi dasar yang berfungsi sebagai landasan manusia untuk menjaga keselarasan dengan alam dengan menghayati keberadaan makhluk gaib tersebut. 


\section{Saling Menghormati dan Saling Menjaga antarsesama Makhluk Hidup}

Saling menghormati dan saling menjaga berhubungan dengan sikap manusia untuk menghargai keberagaman. Nilai budaya saling menghormati dan saling menjaga antarsesama makhluk hidup dalam mantra bercocok tanam padi ditemukan pada aspek pemberian rasa hormat kepada sesama makhluk hidup. Nilai budaya tersebut ditunjukkan melalui data Aja salah gawe sing tapa bumi Ronggo kene, aja sira uruk. Berdasarkan data tersebut, nilai budaya saling menghormati dan saling menjaga antarsesama makhluk hidup diwujudkan melalui sikap tidak mengganggu dan tidak merusak kehidupan makhluk hidup lain di alam. Nilai budaya tersebut mengandung ajaran supaya manusia menjaga keharmonisan dengan alam melalui sikap sopan santun antarsesama makhluk. Pernyataan tersebut selaras dengan pernyataan Sujarwa (2011) bahwa manusia yang telah mengenal sifat-sifat alam lingkungan hidupnya dengan baik akan membuat falsafah hidup yang menuntun manusia supaya hidup selaras dengan alam. Nilai budaya saling menghormati dan saling menjaga antarsesama makhluk hidup dalam mantra bercocok tanam padi menuntun manusia supaya berperilaku ideal untuk mencari keselarasan dengan alam.

Nilai budaya saling menghormati dan saling menjaga antarsesama makhluk hidup dalam mantra bercocok tanam padi menjadi rujukan yang berfungsi memberikan petunjuk bahwa selama melaksanakan proses bercocok tanam padi manusia dengan makhluk hidup lain hendaknya saling menjaga dan saling menghormati. Kedudukan dan fungsi nilai budaya tersebut selaras dengan pernyataan Saryono (2008: 19) bahwa nilai budaya memiliki kedudukan sebagai rujukan atau acuan yang berfungsi menunjukkan apa yang boleh dan baik serta apa yang tidak boleh dan tidak baik diikuti oleh ucapan, tindakan, perbuatan, dan perilaku manusia. Nilai budaya tersebut memberikan petunjuk supaya manusia dengan makhluk hidup lain di alam saling tidak mengganggu dan tidak saling menyakiti sehingga dapat tercipta keharmonisan antarsesama makhluk hidup.

\section{Tidak Menyakiti Makhluk Hidup di Alam}

Nilai budaya tidak menyakiti makhluk hidup yang ada di alam dalam mantra bercocok tanam padi ditemukan pada aspek cara memanen padi. Nilai budaya tersebut ditunjukkan melalui data Gamane pangetwaja udhunan ko 
suwarga, sing tak salami jangga sira. Berdasarkan data tersebut, nilai budaya tidak menyakiti makhluk hidup diwujudkan melalui upaya manusia untuk tidak menyiksa atau menyakiti tanaman padi yang diwujudkan melalui sikap hati-hati ketika memotong padi. Nilai budaya tersebut mengandung ajaran supaya manusia menjaga keharmonisan dengan alam melalui rasa cinta berupa perasaan belas kasih kepada padi ketika dipetik. Pernyataan tersebut selaras dengan pernyataan Saryono (2008: 170) bahwa nilai kecintaan manusia Jawa berkenaan dengan kesanggupan dan kesediaan manusia untuk mewujudkan kesukaan, kesenangan, kepercayaan, kehargadirian, dan ketulusan kepada sesama manusia dan alam semesta. Nilai budaya tidak menyakiti makhluk hidup di alam dalam mantra bercocok tanam padi mengarahkan manusia supaya mencintai makhluk hidup di alam semesta sehingga tercipta keselarasan dengan alam.

Nilai budaya tidak menyakiti makhluk hidup di alam dalam mantra bercocok tanam padi menjadi rujukan yang berfungsi memberikan petunjuk kepada manusia supaya tidak menyakiti makhluk hidup di alam dan supaya manusia memiliki rasa cinta terhadap alam semesta selama melaksanakan proses bercocok tanam padi. Kedudukan dan fungsi nilai budaya tersebut selaras dengan pernyataan Saryono (2008: 19) bahwa nilai budaya memiliki kedudukan sebagai rujukan atau acuan yang berfungsi menunjukkan apa yang boleh dan baik serta apa yang tidak boleh dan tidak baik diikuti oleh ucapan, tindakan, perbuatan, dan perilaku manusia. Nilai budaya tersebut memberikan petunjuk supaya manusia memiliki rasa kasih sayang dan tidak menyakiti makhluk hidup lain di alam.

\section{Menghargai Keberagaman di Alam}

Keberagaman adalah suatu keadaan yang di dalamnya terdapat perbedaanperbedaan dalam berbagai hal (Sujarwa, 2012: 243). Nilai budaya menghargai kebergaman di alam dalam mantra bercocok tanam padi ditemukan pada aspek toleransi terhadap keberagaman makhluk. Nilai budaya tersebut ditunjukkan melalui data Mbok Sri Penganti, Mbok Sri Penganten, Mbok Sri Dono, Mbok Sri Kuning, Mbok Sri Abang, ora ana sing tak arani ala, becik kabeh. Berdasarkan data tersebut, nilai budaya menghargai keberagaman diwujudkan melalui sikap tidak saling menjelekkan antarsesama makhluk yang hidup. Nilai budaya tersebut mengandung ajaran bahwa bermacam-macam jenis makhluk hidup di alam tidak 
ada yang lebih baik atau lebih buruk daripada yang lain. Pernyataan tersebut selaras dengan pernyataan Saryono (2008: 193) bahwa nilai kemanusiawian manusia Jawa menjunjung dan menghormati harkat dan martabat makhluk hidup salah satunya dengan menjauhi sikap, ucapan, atau tindakan menjelek-jelekkan orang lain. Nilai budaya tersebut juga mengajarkan manusia untuk menjaga keharmonisan antarsesama makhluk hidup dengan menghargai dan mentoleransi keberagaman jenis makhluk hidup. Pernyataan tersebut selaras dengan pernyataan Saryono (2008: 158) bahwa nilai ketenggangrasaan atau ketoleranan manusia Jawa berkenaan dengan kemampuan menghormati, menghargai, serta menjaga keberadaan dan keadaan manusia sehingga masing-masing sama-sama leluasa, bahagia, tidak dirugikan, dan tidak tersinggung. Nilai budaya menghargai keberagaman di alam mengandung ajaran supaya manusia memiliki sikap tenggang rasa atau toleransi terhadap keberagaman makhluk hidup.

Nilai budaya menghargai keberagaman dalam mantra bercocok tanam padi menjadi pengendali yang berfungsi mengarahkan manusia untuk menghargai dan mentoleransi keberagaman jenis makhluk yang hidup di alam. Kedudukan dan fungsi nilai budaya tersebut selaras dengan pernyataan Saryono (2008: 17) bahwa nilai budaya memiliki kedudukan sebagai pengendali yang berfungsi mengarahkan dan menjaga ucapan, tindakan, perbuatan, dan perilaku manusia dalam hidup dan kehidupan. Nilai budaya tersebut mengarahkan dan menjaga ucapan dan tidakan manusia supaya tidak membeda-bedakan dan tidak menjelekjelekkan antarsesama makhluk hidup.

\section{Nilai Budaya dalam Hubungan Manusia dengan Manusia Lain}

Nilai budaya dalam hubungan antara manusia dengan manusia lain dalam mantra bercocok tanam padi memiliki wujud sebagai berikut.

\section{Tidak Mengambil Milik Orang Lain}

Tidak mengambil milik orang lain merupakan sikap manusia untuk tidak mengambil apa yang menjadi hak orang lain tanpa izin. Nilai budaya tidak mengambil milik orang lain dalam mantra bercocok tanam padi ditemukan pada aspek pemenuhan kebutuhan hidup. Nilai budaya tersebut ditunjukkan melalui data Sanak sedulur goleko sandhang pangan dewe-dewe. Berdasarkan data tersebut, nilai budaya tidak mengambil milik orang lain diwujudkan melalui sikap 
tidak mengambil barang milik orang lain tanpa izin yang diwujudkan melalui kerja keras untuk memenuhi kebutuhan hidupnya sendiri. Nilai budaya tersebut mengandung ajaran untuk menjaga kerukunan antarsesama manusia dengan tidak bersikap egois dan tidak mengambil milik orang lain. Pernyataan tersebut selaras dengan pernyataan Saryono (2009: 88) bahwa penghindaran konflik yang dapat mengganggu atau merusak kerukunan dapat dilakukan dengan pengendalian diri dari nafsu dan egoisme dengan baik. Nilai budaya tidak mengambil milik orang lain dapat dijadikan tuntunan supaya manusia dapat menjaga kerukunan sebagai makhluk sosial dengan berusaha memenuhi kebutuhan pribadi tanpa mengambil barang atau sesuatu milik orang lain.

Nilai budaya tidak mengambil milik orang lain dalam mantra bercocok tanam padi menjadi rujukan yang berfungsi memberikan petunjuk kepada manusia supaya berusaha untuk memenuhi kebutuhan hidupnya sendiri sehingga tidak perlu merebut atau mengambil sesuatu milik orang lain tanpa izin. Kedudukan dan fungsi nilai budaya tersebut selaras dengan pernyataan Saryono (2008: 19) bahwa nilai budaya memiliki kedudukan sebagai rujukan atau acuan yang berfungsi menunjukkan apa yang boleh dan baik serta apa yang tidak boleh dan tidak baik diikuti oleh ucapan, tindakan, perbuatan, dan perilaku manusia. Nilai budaya tersebut memberikan petunjuk supaya manusia tidak mengambil milik orang lain untuk memenuhi kebutuhan hidup.

\section{PENUTUP}

\section{Simpulan}

Merujuk pada fokus penelitian diperoleh simpulan bahwa dalam mantra bercocok tanam padi terdapat nilai budaya yang terlihat melalui empat pola hubungan manusia, yakni nilai budaya dalam hubungan manusia dengan diri sendiri, Tuhan, alam, dan manusia lain. Dari empat nilai budaya tersebut yang paling dominan ditemukan adalah nilai budaya dalam hubungan manusia dengan Tuhan karena mantra merupakan bentuk sastra lisan yang cenderung berisi permohonan manusia kepada Tuhan.

\section{Saran}

Merujuk pada simpulan, dikemukakan saran terkait penelitian ini. Pertama, kepada peneliti selanjutnya disarankan untuk melakukan penelitian dengan fokus 
yang lebih mendalam, yakni mengkaji mantra pada aspek implementasinya. Kedua, kepada lembaga penelitian disarankan untuk mendokumentasikan dan menginventaris mantra yang dilestarikan oleh masyarakat Indonesia supaya tidak punah. Ketiga, kepada masyarakat Indonesia disarankan untuk tetap melestarikan penggunaan mantra dan mewariskan kepada generasi selanjutnya supaya mantra tersebut tetap hidup dan berkembang.

\section{DAFTAR RUJUKAN}

Amir, Adriyetti. 2013. Sastra Lisan Indonesia. Yogyakarta: ANDI.

Danandjaja, James. 1994. Folklor Indonesia: Ilmu Gosip, Dongeng, dan LainLain. Jakarta: PT. Pustaka Utama Grafiti.

Djamaris, Edwar, dkk. 1996. Nilai Budaya dalam Beberapa Karya Sastra Nusantara: Sastra Daerah di Kalimantan. Jakarta: Pusat Pembinaan dan Pengembangan Bahasa Departemen Pendidikan dan Kebudayaan.

Gunawan, Heri. 2012. Pendidikan Karakter: Konsep dan Implementasi. Bandung: Alfabeta.

Hasjim, Nafron. 1994. Sastra Daerah di Kalimantan (Kalimantan Barat, Kalimantan Tengah, dan Kalimantan Timur): Analisis Tema, Amanat, dan Nilai Budaya. Jakarta: Departemen Pendidikan dan Kebudayaan Pusat Pembinaan dan Pengembangan Bahasa.

Kesuma, Dharma; Triatna, Cepi; Permana, Johar. 2012. Pendidikan Karakter: Kajian Teori dan Praktik di Sekolah. Bandung: PT Remaja Rosdakarya.

Kodiran. 2002. Kebudayaan Jawa. Koentjaraningrat (Ed). Manusia dan Kebudayaan di Indonesia. Jakarta: Penerbit Djambatan.

Koentjaraningrat. 2000. Bunga Rampai Kebudayaan Mentalitas dan Pembangunan. Jakarta: PT Gramedia Pustaka Utama.

Roqib, Moh. 2007. Harmoni dalam Budaya Jawa: Dimensi Edukasi dan Keadilan Gender. Yogyakarta: Pustaka Pelajar.

Saryono, Djoko. 2008. Etika Jawa dalam Fiksi Indonesia: Representasi NilaiNilai Etis Jawa. Malang: Pustaka Kayutangan.

Saryono, Djoko. 2008. Paras Nilai Budaya: Konsepsi, Klasifikasi, dan Transformasi. Malang: Surya Pena Gemilang.

Saryono, Djoko. 2009. Fiksi Indonesia Berparas Falsafah Jawa: Konstruksi Literel Nilai Filosofis Jawa. Malang: Pustaka Kayutangan.

Saryono, Djoko. 2009. Suara Sufistis dan Religius dalam Sastra. Malang: Asah Asih Asuh.

Sorayah, Yayah. 2014. Fungsi dan Makna Mantra Tandur di Desa Karangtunggal, Kecamatan Cibeber, Kabupaten Cianjur. Bahtera Sastra: Antologi bahasa dan Sastra Indonesia, 2 (2). (Online), (Http://www.ejournal.upi.edu), diakses tanggal 01 Oktober 2016.

Sudikan, Setya Yuwana. 2001. Metode Penelitian Sastra Lisan. Surabaya: Citra Wacana. 
Sujarwa. 2011. Ilmu Sosial dan Budaya Dasar: Manusia dan Fenomena Sosial Budaya. Yogyakarta: Pustaka Pelajar.

Sulaeman, Munandar.1998. Ilmu Budaya Dasar: Suatu Pengantar. Bandung: PT. Refika Aditama.

Widodo, Wahyu. 2012. Kearifan Lokal dalam Mantra Jawa. Disajikan pada Prosiding the $4^{\text {th }}$ International Conference on Indonesian Studies, Fakultas Ilmu Budaya, Universitas Indonesia, Bali, 9-10 Februari 2012. (Online), (Http://icssis.files.wordpress.com), diakses tanggal 01 Oktober 2016. 